\title{
DEVELOPING A GIS-BASED INVENTORY FOR THE IMPLEMENTATION OF CAVE MANAGEMENT PROTOCOLS IN WITHLACOOCHEE STATE FOREST, FLORIDA
}

\section{INTRODUCTION}

Geographic Information Systems (GIS) are used in a variety of fields such as urban and regional planning (Dai et al., 2001; Jankowski, 1989), criminology (Brantingham and Brantingham, 1995; Chainey and Ratcliffe, 2005), and natural sciences (Carrara et al., 1991; Goodchild, 1993). GIS is now being applied to various aspects of cave and karst science for its ability to integrate data storage with a spatial component. The integration of GIS with karst research has furthered the study of speleogenesis (Horrocks and Szukalski, 2002; Hung et al., 2002), cave ecosystems (Despain and Fryer, 2002), cave geomorphology and hydrology (Florea et al., 2003; Florea, 2006), the consideration of caves as a monetary resource for tourism (Ohms and Reece, 2002), cave archaeology (Moyes, 2002), and the human disturbance of karst environments (van Beynen and Townsend, 2005). In this paper, we present a new method for using GIS to inventory cave contents for resource management purposes.

More than $25 \%$ of the world's population either lives on or obtains drinking water from karst terranes, with caves being an integral component of karst landscapes (KWI, 2009). Understanding caves as natural systems and potential groundwater resources is the key to their management and protection, with the first step being to conduct a cave inventory (DuChene, 2006). However, cave inventories are not widely published in the popular and professional press, vary in both purpose and method, and are often subjective with respect to the amount and type of data included. Assimilating GIS with methodologies associated with the inventory of cave resources and utilization patterns could make the paper-form inventory of cave systems obsolete, thereby moving towards more comprehensive data collection and user flexibility.

This project was initiated through a collaborative effort between the Withlacoochee State Forest (WSF) and the Department of Geography at the University of South Florida. Prior to this project, state forest personnel had limited knowledge of their caves and expressed the need for a comprehensive cave management strategy. The research design for this study was to develop and test a method for conducting inventories in WSF terrestrial caves using GIS, thereby allowing state forest personnel to easily access and manipulate data, and provide a replicable method for future inventories of other cave systems in west-central Florida. Given the widespread lack of cave management in WSF, the inventory served as the first account of cave contents in WSF and the first step in developing ongoing management strategies.

\footnotetext{
${ }^{1}$ Department of Geography, University of Tennessee, 304 Burchfiel Geography Building, Knoxville, TN 37996, glharley@gmail.com

${ }^{2}$ Department of Geography, University of South Florida, 4202 E. Fowler Ave., Tampa, FL,33620,preeder@cas.usf.edu, vanbeyne@cas.usf.edu

${ }^{3}$ Hoffmon Environmental Research Institute, Department of Geography and Geology, Western Kentucky University, 1906 College Heights Blvd., Bowling Green, KY, 42101, jason.polk@wku.edu
} 


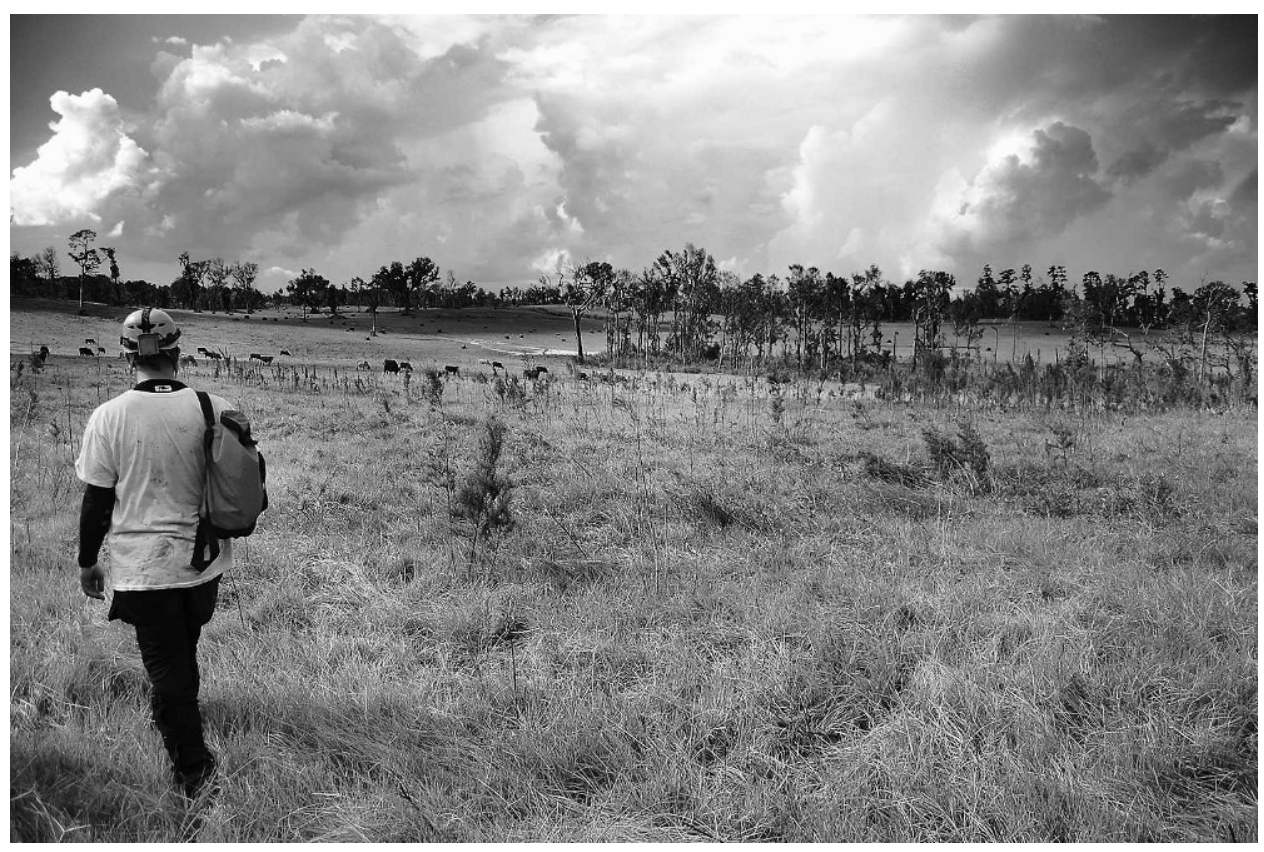

Figure 1. Gentle, rolling topography near Withlacoochee State Forest, Brooksville, Florida. In the background is an upland mesic-hardwood hummock adjacent to a sinkhole lowland in the foreground.

The overall purpose of this study was to create a modernized and user-friendly GIS-based method of cave inventory that encompasses all aspects of the inventory (i.e., data collection, storage, manipulation, and postprocessing) for the efficient management of caves in WSF. This article presents a GIS-based method and database design the authors developed to facilitate cave inventories in WSF.

\section{Background: Cave Inventory}

Since the 1700s, cave inventories involved cataloging biota, archaeological sites, and fossil deposits (DuChene, 2006). A number of different groups have conducted cave inventories throughout the United States with varying objectives (Brown and Kirk, 1999; Douglas, 1999; DuChene, 2006). Data collected during these inventories included a wide variety of cave features and their attributes. However, the actual practice of field data collection has lacked a modern, standardized method. Although paper inventory forms are the most widely used and accepted tool for recording cave inventory data (DuChene, 2006), they are especially difficult to use in tight, wet, and muddy cave environments, as experienced in the preliminary stages of this project. These conditions made it necessary to utilize alternative means of data collection that could withstand the rigors of harsh cave conditions. Since the advent of GIS, researchers have realized the potential of combining cave inventory data and GIS (Knutson, 1997; Pfaff et al., 2000; McNeil et al., 2002; Moyes, 2002; Horrocks and Szukalski, 2002; Ohms and Reece, 2002; Despain and Fryer, 2002; Walz and Spoelman, 2005). By integrating GIS with previous forms of inventory, additional data can be collected in a quicker, more efficient manner, thus reducing the cost and staffing needs, and eliminating the aforementioned problems associated with paper inventory forms.

\section{Study Area}

WSF is a vast stretch of land in west-central Florida that covers approximately $637 \mathrm{~km}^{2}$ and spans four counties (Citrus, Pasco, Hernando, and Sumter). The karst features found in WSF include: springs, sinkholes, and terrestrial caves. Currently, there are 19 known caves located in WSF, all of which are developed within the Brooksville Ridge. The Brooksville Ridge is the largest of the ridges located in the Central Upland of the Florida Peninsula (White, 1970). Elevations vary throughout its length from 21 to $60 \mathrm{~m}$ above mean sea level. The topography is rolling hills with internal drainage occurring mostly through caves associated with the Floridan Aquifer System. Additionally, upland mesic-hardwood hummocks separate sinkhole lowlands that are mostly occupied by wetlands or lakes (Florea, 2006) (Fig. 1). The WSF caves are all located within the Citrus Tract, which is positioned on the border of Citrus and Hernando Counties (Fig. 2). WSF is stateowned, public land and any recreational activity requires a special-use permit, including cave access.

\section{Methods}

\section{Locating CAVES For InVEnTORY}

All 19 known caves within WSF were visited in the spring of 2007 in order to assemble a detailed record of 


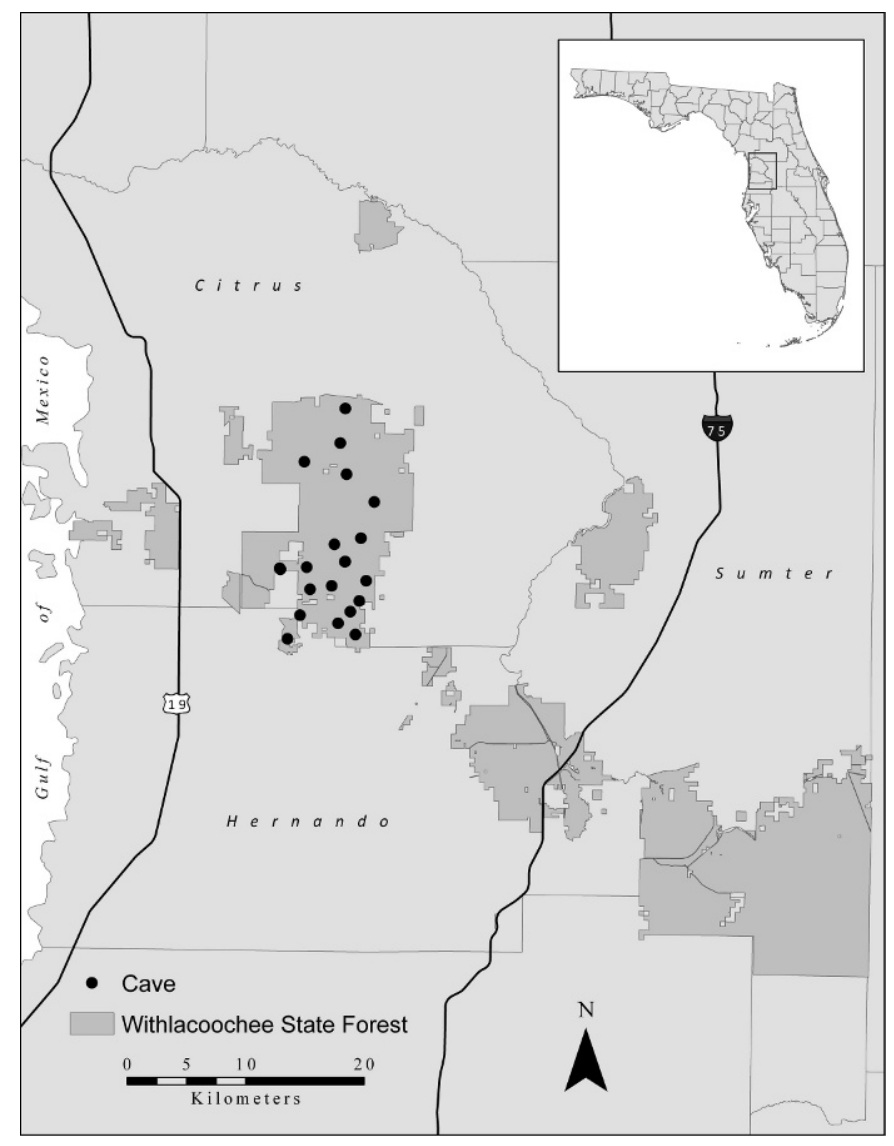

Figure 2. Location of caves within Withlacoochee State Forest, Florida.

resources using a GIS-based inventory. A Global Positioning System (GPS) was linked with ESRI ArcPad 7.1, which allowed for cave entrance location acquisition in the field and storage directly into the geodatabase (Fig. 3). ArcPad 7.1 is GIS software for mobile devices and provides the ability to collect field data in a reliable and efficient manner (Clarke et al., 2002). A mobile Haicom HI-303III GPS unit was used to locate cave entrances with known waypoints. However, caves with unknown waypoints were marked in the field using the mobile GPS unit. Because of the link between GPS and GIS, these caves were immediately added to ArcPad 7.1 and made available for inventory data input directly in the geodatabase.

\section{INVENTORY FRAMEWORK AND CONTENTS}

The cave inventory framework is based on a paper inventory model described by O'Dowd and Broeker (1996). This inventory model was one of the most comprehensive inventory models available and proved to be easily adaptable to suit the objectives of this project. The inventory model was adjusted to comprehensively fit in a GIS geodatabase by creating categorized attributes with detailed descriptions and fields for data input. Cave-survey data containing stations were necessary to give cave

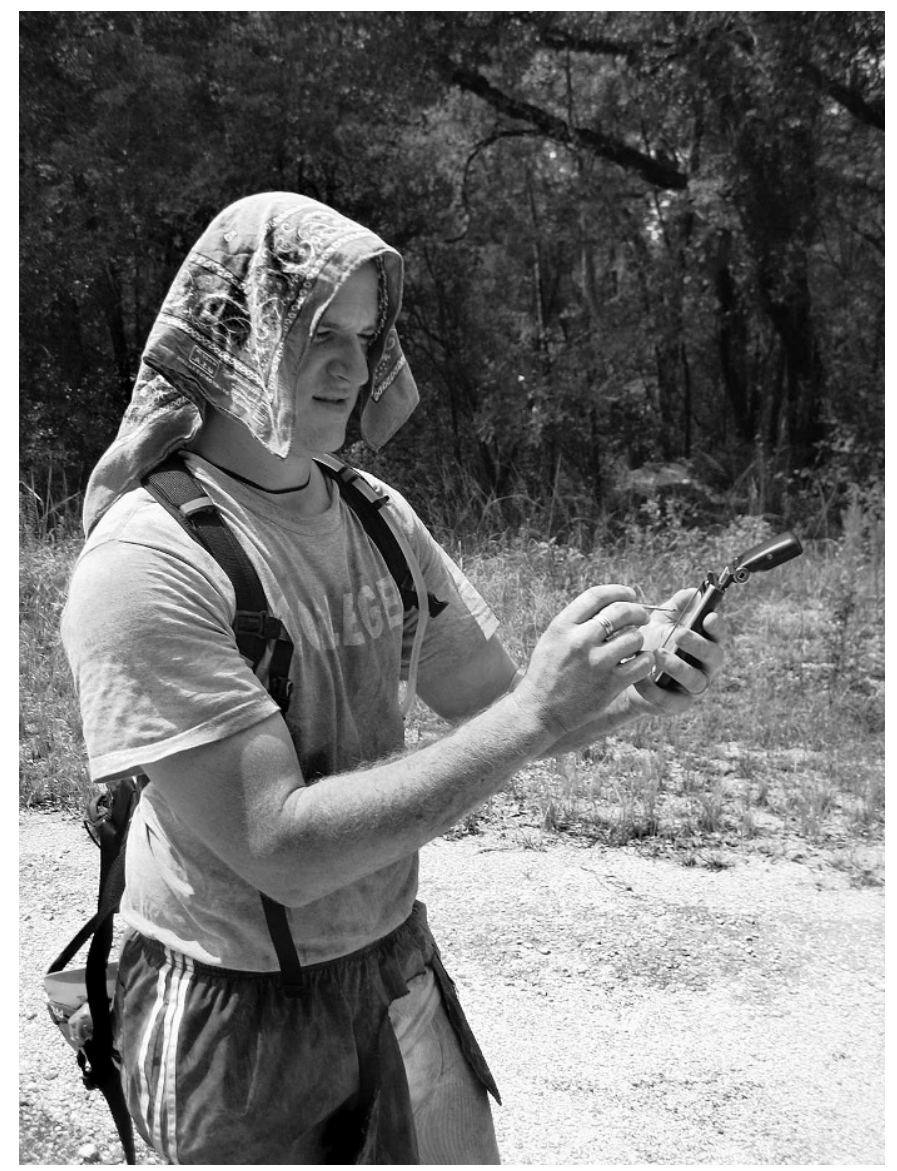

Figure 3. A mobile GPS unit was linked with the PDA to facilitate the acquisition of cave locations.

resources a reference point during inventory. Each survey station was given an absolute location based upon the entrance GPS data. Several caves in WSF were previously surveyed and maps were acquired from the cartographers. However, the majority of caves were simultaneously surveyed and inventoried, which is a widely practiced and accepted method (Ohms and Reece, 2002; Horrocks and Szukalski, 2002; DuChene, 2006). For caves lacking an existing survey, one was conducted using a compass, inclinometer, and tape (Dasher, 1994). A detailed account of specific cave contents was inventoried at each survey station. Features within each cave located between survey stations were assigned to the closest survey station. These parameters are presented in the geodatabase data dictionary, which is used to describe each field and its possible values (Table 1).

\section{Using GIS For CAVE InVEntory}

Collecting and storing inventory data in the same step was a more efficient method that saved time and work and eliminated human error during the process of data transcription from paper forms. In order to facilitate data collection, ArcPad 7.1 was loaded onto a Dell Axim X51 personal digital assistant (PDA) (Fig. 4). An Aqua Quest 
Table 1. Geodatabase Data Dictionary.

Attribute Name

Name

Inventory Date

Inventory ID

Township

Range

Section

County

Personnel

Cave Ownership

Equipment Needed

Other Equipment Needed

Elevation

Cave Map Status

Cave Length

Cave Vertical Extent

Management Notes

Entry Status

Multiple Entrances

Type Of Entrance: Vertical

Type Of Entrance: Horizontal/

Downward Sloping

Entrance Topo Position

Entrance Visibility

Entrance Modification

Entrance Min Size

Entrance Drop Depth

Entrance Notes

Passage Orientation

Passage Types

Passage Min Sizes

Passage Hydrology

Passage Floor

Passage Hazards
Description

All known names of cave

Date the inventory was conducted

Unique ID given to each cave for geodatabase identification

Township in which cave is located (Public Land Survey System)

Range in which cave is located (Public Land Survey System)

Section in which cave is locate (Public Land Survey System)

Florida county in which cave is located

People who conducted inventory

Ownership of cave. Values = Commercial, Private, Public, Government Park, Unknown Status

Equipment needed to cave. Values = Boat or Floatation, Diving Equipment, Handline, Kneepads, Cable ladder, Normal Speleo Gear, Shovel-Blasting, Rope or Vertical Equipment, Other special equipment, Unknown, Wet-Suit, Mask/ snorkel, None, NA

Same values as Equipment Needed (above) to list multiple equipment needs

Elevation of cave entrance in meters above mean sea-level

Current status of cave map. Values = Improved map, New map/survey, Redraw of old map, In progress, No map, Complete map, Sketch only, not to scale

Current surveyed length of cave (m)

Current surveyed vertical extent of cave (m)

Notes pertaining to the management of cave

Accessibility of cave. Values = Fees charged for entry, Destroyed or closed, Forbidden by owner, Locked/Gated, Navigable Waterway, Open access, Permission required, Waiver required, Temporarily blocked, Unknown status, NA

Indicates whether there are multiple entrances to cave. Values $=\mathrm{Y}(\mathrm{Yes})$ or $\mathrm{N}$ (No)

Indicates type of cave entrance if vertical. Values = Artificial shaft, Bottleneck/ small but bells out, Chimney/climb, Very wide pit (+20 ft), Pit, Tight pit, Enlarged fissure, Tight squeeze, NA

Indicates type of cave entrance if horizontal or downward sloping. Values $=$ Large horizontal (+ $20 \mathrm{ft})$, Stoop/duck walk, Crawl, Artificial tunnel, Tight squeeze, NA

Describes the topographic position of the cave entrance. Values $=$ Sinkhole, Hillside, Topographic low, Hilltop, Quarry, Floodplain, etc.

Indicates visibility of cave entrance. Values = Clearly visible, Obscured by vegetation, Obscured by rocks, etc.

Describes any modifications made to the cave entrance. Values $=$ Widened, Artificial entrance, Gated, Road construction, Quarry, Blocked, Dug out/open

Indicates the minimum size of cave entrance. Values = Squeeze, Crawl, Stoop, Walk, Vertical drop

Depth of entrance drop if vertical (m)

Any notes relating to cave entrance

Passage orientations per survey station. Values $=$ N-S, E-W, NE-SW, NW-SE, NE-SW \& NW-SE, NE-SW \& NW-SE \& N-S \& E-W

Passage type per survey station. Values = enlarged fissure, key hole, plus-sign, breakdown, phreatic, etc.

General size of passage per survey station. Values = squeeze, crawl, stoop, walk, etc. Hydrological resources per survey station. Values = seeps, drips, pool, aquifer, NA, etc.

Floor type per survey station. Values = sediment, clay, breakdown, etc.

Possible hazards per survey station. Values $=$ guano, unstable breakdown, steep drop, etc. 
G.L. Harley, P.P. Reeder, J.S. Polk, and P.E. van Beynen

Table 1. Continued.

\begin{tabular}{|c|c|}
\hline Attribute Name & Description \\
\hline Passage Notes & Notes pertaining to passage characteristics \\
\hline Tites/Mites/Columns/Condition & $\begin{array}{l}\text { Stalactites, stalagmites, and/or columns and condition (depositing, dry, damaged } \\
\text { etc.) per survey station. NA = Not Applicable }\end{array}$ \\
\hline Drapery Condition & Drapery and condition per survey station $. \mathrm{NA}=$ Not Applicable \\
\hline Helictites Condition & Helictites and condition per survey station. $\mathrm{NA}=$ Not Applicable \\
\hline Rimstone Condition & Rimstone and condition per survey station. $\mathrm{NA}=$ Not Applicable \\
\hline Popcorn Condition & Popcorn and condition per survey station. NA $=$ Not Applicable \\
\hline Flowstone Condition & Flowstone and condition per survey station. $\mathrm{NA}=$ Not Applicable \\
\hline Spar Condition & Spar and condition per survey station. NA $=$ Not Applicable \\
\hline Calcite Coating & Calcite coating and description per survey station. $\mathrm{NA}=$ Not Applicable \\
\hline Calcite Rafts & Calcite rafts and description per survey station. $\mathrm{NA}=$ Not Applicable \\
\hline Ripple Marks/Scallops & Ripple marks and/or scallops per survey station. NA $=$ Not Applicable \\
\hline Anastomoses & Anastomoses per survey station. NA $=$ Not Applicable \\
\hline Sediments & $\begin{array}{l}\text { Describes sediment per survey station in cave. Values = sorted, unsorted, clay, } \\
\text { fine lamination, organics present, etc. }\end{array}$ \\
\hline Sediment Notes & Any notes relating to cave sediments \\
\hline Fossils & Location and description of fossils per survey station. NA $=$ Not Applicable \\
\hline Bones & Location and description of bones per survey station. NA $=$ Not Applicable \\
\hline Geologic Strata & $\begin{array}{l}\text { Geologic unit per survey station. Values = Ocala limestone (Eocene), Suwannee } \\
\text { Limestone (Oligocene), Avon Park Formation (Middle Eocene), Tampa } \\
\text { Member (Arcadia Formation)(Upper Oligocene-Lower Miocene) }\end{array}$ \\
\hline Other Geologic Strata & $\begin{array}{l}\text { Other geologic unit found per survey station. Same values as "Geologic_Strata" } \\
\text { (in case of more than one strata per station) }\end{array}$ \\
\hline Geologic Notes & Any notes for geology of cave \\
\hline Biological Vertebrates & $\begin{array}{l}\text { List and location of biological vertebrates per survey station. NA }=\text { Not } \\
\text { Applicable }\end{array}$ \\
\hline Biological Invertebrates & $\begin{array}{l}\text { List and location of biological invertebrates per survey station. NA }=\text { Not } \\
\text { Applicable }\end{array}$ \\
\hline Mold/Bacteria & $\begin{array}{l}\text { List and location of any mold or bacteria per survey station. NA }=\text { Not } \\
\text { Applicable }\end{array}$ \\
\hline Roots & Location of roots per survey station. NA $=$ Not Applicable \\
\hline Roost Stains & Location of roost stains per survey station. $\mathrm{NA}=$ Not Applicable \\
\hline Guano Piles & Location of guano piles per survey station. NA $=$ Not Applicable \\
\hline Biological Notes & Any notes pertaining to cave biology. \\
\hline Artifacts- Historical & $\begin{array}{l}\text { List and location of possible historical artifacts per survey station. NA }=\text { Not } \\
\text { Applicable }\end{array}$ \\
\hline Cultural Notes & Any notes pertaining to possible cave artifacts. NA $=$ Not Applicab \\
\hline Scientific Potential Area Note & Notes for scientific potential areas (location and description) per survey station \\
\hline Special Interest Areas Note & $\begin{array}{l}\text { Notes for special interest, non-scientific areas (location and description) per } \\
\text { survey station. }\end{array}$ \\
\hline
\end{tabular}

water-proof case was used to ensure the protection of the PDA device while conducting the inventory in wet and/or muddy cave environments (Fig. 5). Certain GIS data layers were loaded into ArcPad 7.1 for use in the field. These layers included: a polygon coverage of Florida counties and roads, a point coverage of WSF cave locations, and a polygon coverage of WSF. Both polygon coverage layers were acquired from the Florida Geographic Data Library and served as a spatial reference for the point coverage of WSF caves that was created during this study. All shapefile layers and the geodatabase were viewable on the PDA, which allowed for editing and updating in the field.
The cave inventory data for each cave was stored in a GIS geodatabase (Table 1). The cave inventory geodatabase was created in ArcCatalog and maintained in ArcMap 9.2, both of which are applications included in the ESRI ArcView 9.2 ArcGIS software package. ArcPad 7.1 and ArcView 9.2 are interchangeable GIS applications, making data transfer from the PDA to the geodatabase straightforward. When data were ready to be transferred to the geodatabase after applying the inventory, the PDA was synced to a personal computer via Microsoft Active Sync version 4.1.0. Once synchronized, the data were copied from the PDA directly to the geodatabase in ArcMap 9.2. 


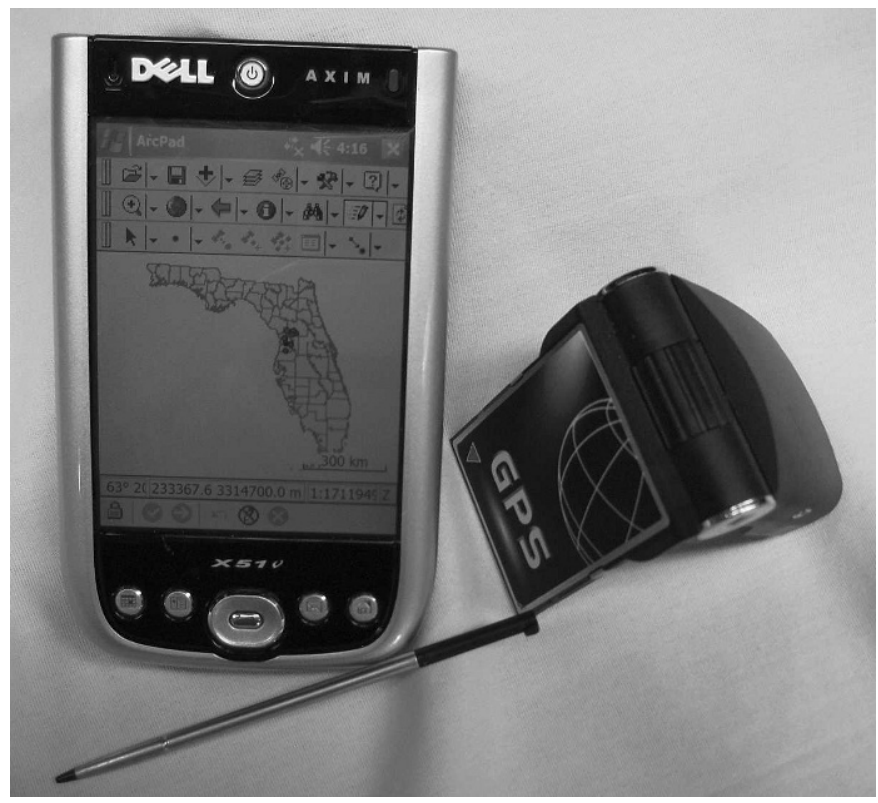

Figure 4. The tools used for inventory data collection in the field included ArcPad 7.1 displayed on a Dell Axim X51 device.

Additionally, each cave was documented with photographs using a digital camera. Documenting cave features with photographs produces a visual representation of those features during the time of inventory and is useful when comparing cave conditions through time (DuChene, 2006).

\section{Field InVEntory Methods}

Cave inventory teams consisted of an average of three people, depending upon the availability of an existing survey. If an accurate survey existed, two people were sufficient; while one read the map and identified resources at and between each survey station, the other input the data into the PDA. If no survey was available, then a threeperson team simultaneously surveyed and inventoried the cave, as the additional person sketched and assisted with the survey/inventory. Every participant in this project was an experienced caver or karst scientist well-versed in the identification of features within the caves.

The inventory of each of the 19 caves in WSF began at the entrance, and included both vertical and horizontal openings. Data collection commenced at the entrance with one person using the PDA to input features found within the cave as identified by the second and/or third individual. Survey stations were used as markers to spatially identify features entered into the geodatabase. This method of data entry continued until the entire cave and its contents were surveyed (if needed) and inventoried.

\section{Database Design}

A comprehensive cave inventory geodatabase was created using the electronic PDA inventory method. The inventory database includes a point shapefile (each point represents a cave) and a database file (dbf). The dbf contains the descriptive data for each cave obtained during inventory in the field (Table 1). This database is easily queried to locate cave features and parameters by WSF personnel, which also allows future updates as cave inventories are added for newly discovered caves, or updates from future inventories of existing caves. By using an electronic cave inventory method, the functionality, comprehensiveness, and transferability of cave inventory data were improved,

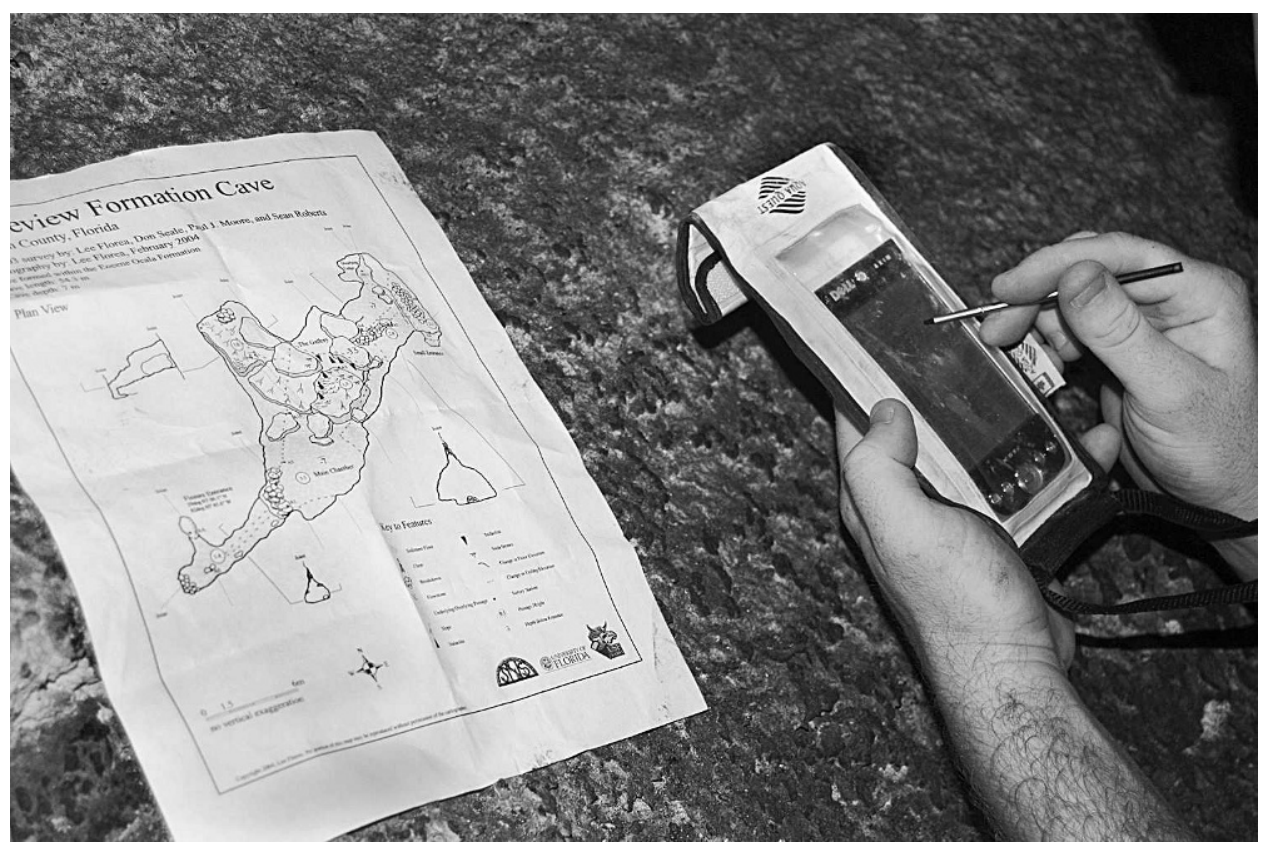

Figure 5. The PDA device was protected in the field with an Aqua Quest, water-proof cover. 
thereby providing WSF personnel with the necessary information to use in managing their caves. Additionally, the variety of fields (Table 1) in the geodatabase allowed for substantial data collection above and beyond that of standard inventories collected by other methods. Cave inventory data are secured via password-protected software used by WSF to guard the inventory information and allow access only by authorized users. Thus, WSF personnel are able to use additional data to manage caves by resources, location, size, features, etc. by querying the geodatabase and utilizing ArcGIS to determine which caves require special management and attention.

WSF personnel are now able to view the exact locations of caves and access the associated attribute table (dbf) to view the cave-specific resources, anthropogenic impacts, and other characteristics of each cave. Knowing the entrance location and attribute data for each cave are the initial steps needed for resource protection and proper management decisions, emergency response planning, prevention of unintentional impacts to cave systems from land management activities such as logging, road maintenance, construction of recreational facilities, prescribed forest burns, exotic plant control, and other activities. By having the ability to query and rank caves based on their features and resources, land managers are able to use the geodatabase to help prioritize cave management based on their needs.

With a comprehensive inventory system in place, WSF continues the inventory of each cave on a regular basis. The inventory system also provides them the basis needed to conduct visitor impact mapping, such as that described in Bodenhamer $(1995,2006)$, as well as implement a GISbased management strategy that geospatially links cave inventory data with each geo-referenced survey station (Despain and Fryer, 2002). By using an easily adapted electronic method for inventory, data fields can be added in the field, and data transcription errors and time are reduced, which is a benefit for management entities such as WSF that have limited personnel and financial resources to address cave protection and management.

This GIS-based method of cave inventory is easily adaptable for use in caves in other karst areas, including water-filled cave systems. The limiting factors are the availability of the necessary computer hardware and software and the expertise to link all the components of the inventory together using GIS. However, these factors can be overcome with expanded funding and staffing. Additionally, those conducting the inventory need to adapt the comprehensive fields included in the geodatabase to include the parameters specific to their particular caves. For example, we tailored the original cave inventory parameters from O'Dowd and Broeker (1996) (which was created for use in Oregon caves) for applicability in caves of west-central Florida. Certain parameters were simply not applicable, as the caves and karst of Oregon differs from Florida.

\section{Mobile GIS as An Inventory Tool}

A new electronic method for cave inventory using ArcGIS and ArcPad allows for enhanced data collection and reduces the need for WSF personnel to conduct and transcribe data acquired during inventories. In this pilot study, the cave inventory geodatabase serves as the first step in developing a cave management strategy for each of the 19 caves in WSF. This first step of understanding cave contents is crucial in drafting, implementing, enforcing, and analyzing sound management policy for each cave. The completion of the inventory in each of the 19 WSF caves reveals several important findings:

1. Several species of invertebrates were discovered in six caves, which were previously unbeknownst to WSF biologists. This demonstrates the need for a biological, project-specific inventory of each cave containing these resources.

2. Pristine speleothems were found in several caves in need of immediate protection from vandals and souvenir-seekers.

3. The data reveal the need for gates on numerous caves, either for resource protection or liability issues brought on by day-use activities.

4. Several caves were found to be in areas of forestpersonnel activity (logging, control burning, cattle grazing, etc.) and procedures can now be implemented to protect the resources found within these caves.

WSF is constantly performing prescribed control burns and granting agricultural lease permits in certain sections of the forest. Forest personnel can now reference the cave inventory geodatabase when making land use decisions. The inventory GIS data also enables WSF personnel to make conservation-wise decisions regarding the relative location of caves in relation to their daily activities which could result in the degradation of a cave environment. This decreases the human-environmental impact and ensures the conservation and protection of each cave in WSF.

Currently, the GIS-based inventory developed for WSF caves is easily applied by state forest personnel and is progressing the drafting of management plans for each cave. Furthermore, we believe this method of inventorying caves should be incorporated in other karst areas, as it can be more beneficial to cave managers than previous methods.

\section{ACKNOWLEDGEMENTS}

We thank the following people: Colleen Werner at Withlacoochee State Forest for supporting this project and providing access to WSF caves; Robert Brinkmann, along with others, for conceiving and promoting this project from its inception; Robert Brooks and Tom Turner for help with locating and inventorying caves; Lee Florea for contributing his cave maps and advice to the project, and 
the Florida Center for Community Design and Research for use of their PDA and software.

\section{REFERENCES}

Bodenhamer, H., 1995, Monitoring human-caused changes with visitor impact mapping, in Proceedings, $10^{\text {th }}$ National Cave Management Symposium, Indianapolis, October 1995, Indiana Karst Conservancy, p. 28-37.

Bodenhamer, H., 2006, Visitor Impact Mapping in Caves, in HildrethWerker, V., and Werker, J.C., eds., Cave Conservation and Restoration, Huntsville, Ala., National Speleological Society, p. 193-202.

Brantingham, P., and Brantingham, P., 1995, Location quotients and crime hotspots in the city, in Block, C., Dabdoub, M., and Fregly, S., eds., Crime analysis through computer mapping, Washington, D.C., Police Executive Research Forum, p. 129-149.

Brown, T., and Kirk, D., 1999, A Karst Resource Inventory of the George Washington and Jefferson National Forests, in Proceedings, $14^{\text {th }}$ National Cave and Karst Management Symposium, October 1999: Chattanooga, Tenn., Southeastern Cave Conservancy, p. 12-18.

Carrara, A., Cardinali, M., Detti, R., Guzzetti, F., Pasqui, V., and Reichenbach, P., 1991, GIS techniques and statistical models in evaluating landslide hazard: Earth Surface Processes and Landforms, v. 16 , p. $427-445$.

Chainey, S., and Ratcliffe, J., 2005, GIS and Crime Mapping, Hoboken, N.J., John Wiley \& Sons, 442 p.

Clarke, S., Greenwald, C., and Spalding, V., 2002, ArcPad 6, Using ArcPad, Redlands, Cal., ESRI, 6 p.

Dai, F.C., Lee, C.F., and Zhang, X.H., 2001, GIS-based geo-environmental evaluation for urban land-use planning: a case study: Engineering Geology, v. 61, no. 4, p. 257-271.

Dasher, G.R., 1994, On Station, Huntsville, Ala., National Speleological Society, $240 \mathrm{p}$.

Despain, J., and Fryer, S., 2002, Hurricane Crawl Cave: A GIS-based cave management plan analysis and review: Journal of Cave and Karst Studies, v. 64, no. 1, p. 71-76.

Douglas, J., 1999, Historic Preservation at Hubbards Cave: Inventory and Management of Cultural Resources, in Proceedings, $14^{\text {th }}$ National Cave and Karst Management Symposium, October 1999: Chattanooga, Tenn., Southeastern Cave Conservancy, p. 46-50.

DuChene, H.R., 2006, Resource Inventory: A Tool for Cave Science, Management, and Restoration, in Hildreth-Werker, V., and Werker, J.C., eds., Cave Conservation and Restoration, Huntsville, Ala., National Speleological Society, p. 19-32.

Florea, L.J., 2006, Architecture of air-filled caves within the karst of the Brooksville Ridge, west-central Florida: Journal of Cave and Karst Studies, v. 68, no. 2, p. 64-75.

Florea, L.J., Hashimoto, T., Kelley, K.N., Miller, D., and Mrykalo, R., 2003, Karst Geomorphology and Relation to the Phreatic Surface, Briar Cave, Marion County, Florida, in Florea, L.J., Vacher, H.L., and Oches, E.A., eds., Karst Studies in West Central Florida, Brooksville, Fla., Southwest Florida Water Management District, p. $9-19$.

Goodchild, M.F., 1993, The state of GIS for environmental problem solving, in Goodchild, M.F., Parks, B.O., and Steyaert, L.T., eds., Environmental Modeling with GIS, New York, Oxford University Press, p. 8-15.

Horrocks, R., and Szukalski, B.W., 2002, Using geographic information systems to develop a cave potential map for Wind Cave, South Dakota: Journal of Cave and Karst Studies, v. 64, no. 1, p. $63-$ 70.

Hung, L.Q., Dinh, N.Q., Batelaan, O., Tam, V.T., and Lagrou, D., 2002, Remote sensing and GIS-based analysis of cave development in the Suoimuoi Catchment (Son La - NW Vietnam): Journal of Cave and Karst Studies, v. 64, no. 1, p. 23-33.

Jankowski, P., 1989, Mixed-data multicriteria evaluation for regional planning: a systematic approach to the decision-making process, Environment and Planning, v. 21, p. 349-362.

KWI, 2009, Karst Waters Institute, http://www.karstwaters.org/ [accessed October 10, 2008].

Knutson, S., 1997, Cave maps as geographical information systems: An example from Oregon Caves National Monument, in Proceedings, $13^{\text {th }}$ National Cave and Karst Management Symposium, October 1997: Chattanooga, Tenn., Southeastern Cave Conservancy, p. 116.

McNeil, B.E., Jasper, J.D., Luchsinger, D.A., and Rainsmier, M.V., 2002, Implementation and application of GIS at Timpanogos Cave National Monument, Utah: Journal of Cave and Karst Studies, v. 64 , no. 1 , p. $34-37$.

Moyes, H., 2002, The use of GIS in the spatial analysis of an archaeological cave site: Journal of Cave and Karst Studies, v. 64, no. 1 , p. $9-16$.

O’Dowd, J., and Broeker, L., 1996. Cave Management Handbook, http:// www.fs.fed.us/r6/umpqua/publications/cave-mgt-handbook-12-02-04 files/cave-mgt-handbook-12-02-04htm\#_Toc8724 5850 [accessed September 21, 2008].

Ohms, R., and Reece, M., 2002, Using GIS to manage two large cave systems, Wind and Jewel Caves, South Dakota: Journal of Cave and Karst Studies, v. 64, no. 1, p. 4-8.

Pfaff, R., Glennon, J., Groves, C., Meiman, J., and Fry, J., 2000, Geographic information systems as a tool for the protection of the Mammoth Cave karst aquifer, Kentucky, in Proceedings, $8^{\text {th }}$ Mammoth Cave Science Conference: Mammoth Cave, Kentucky, National Park Service, p. 89-99.

Van Beynen, P., and Townsend, K., 2005, A Disturbance Index for Karst Environments: Environmental Management, v. 36, no. 1, p. 101-116.

Walz, J., and Spoelman, S., 2005, Integrating Cave and Karst Inventory Methods with GIS, 2003-2004 Cave and Karst Inventory Project, Wind Cave National Park, Inside Earth: Wind Cave National Park, National Park Service, v. 8, no. 1, p. 17-24.

White, W.A., 1970, The Geomorphology of the Florida Peninsula: State of Florida Department of Natural Resources Geological Bulletin 51, $164 \mathrm{p}$. 